\title{
Mineralogy and Geochemistry of the Weathering Profiles above the Basement Rocks in Idi- Ayunre and Akure Districts, Southwestern Nigeria
}

\author{
Adewole J. Adeola ${ }^{1} \&$ Abisola M. Oyebola ${ }^{1}$ \\ ${ }^{1}$ Department of Geology and Mineral Sciences, Crawford University, Igbesa, Nigeria \\ Correspondence: Adewole J. Adeola, Department of Geology and Mineral Sciences, Crawford University, Igbesa, \\ Nigeria. Tel: 234-803-812- 0171. E-mail: kiwoleadeola@yahoo.com
}

Received: December 6, 2015

Accepted: December 21, 2015

Online Published: March 16, 2016

doi:10.5539/jgg.v8n2p15

URL: http://dx.doi.org/10.5539/jgg.v8n2p15

\begin{abstract}
Idi-ayunre and Akure areas are part of the basement complex of southwestern Nigeria and are predominantly consisted of gneisses, granite and migmatite with some minor quartz veins and pegmatite. These rocks have been greatly weathered to form clay, laterite and soils.

Chemical analysis were carried out on basement rocks and exposed profiles. The weathering profile was subjected to $\mathrm{X}$ ray diffraction (XRD) analysis to determine mineralogical compositions whereas Chemical Index of Alteration (CIA) was calculated from the elemental concentrated data.

Weathering of basement rocks in Idi-Ayunre and Akure districts resulted in the formation of soil layer which ranged 0-0.4m, laterite layer 1.2-2.2m, and clayey zone 3.8-6.6m. Quartz, plagioclase, microcline, and biotite were the main minerals in parent rocks. Some of the primary minerals such as biotite and K-feldspar have been weathered to form kaolinite. Quartz, kaolinite and goethite formed the dominant minerals revealed by X-ray diffraction on decomposed granite sequences. The results from chemical analysis showed that $\mathrm{Al}$ and $\mathrm{Fe}$ have been enriched in weathering profiles of banded gneiss, migmatite gneiss and porphyritic granite whilst on the other hand $\mathrm{Ca}, \mathrm{Mg}, \mathrm{Mn}, \mathrm{Na}, \mathrm{K}$, Ti were reported to be depleted.. Silica was relatively stable from basement to the topsoil in the profile. The CIA generally ranged between 80 - 99

The lateritic profiles over banded gneiss, granite and porphyritic granite of Idi-Ayunre and Akure areas varied with the composition of the parent rocks. The thick clayey layers could be of great economic importance for the production of ceramics wares and for constructional purposes.
\end{abstract}

Keywords: basement, weathering, kaolinite, laterite, Nigeria

\section{Introduction}

The majority of the soils present in the tropics are reddish soils called lateritic soils or laterite soils according to Anupam S. and Rajamani V. (2000). Lateritic soils are the commonest tropical soils and they are widely distributed soils in southwestern Nigeria in an area is characterized by tropical climate. Lateritic soils are essentially product of tropical or subtropical weathering of various crystalline igneous rocks, sediments, detrital deposits and volcanic ash. The climatic conditions favorable for laterization include: the warm and humid atmospheric conditions, abundant and regular rainy seasons with well defined dry and wet seasons,

The Precambrian basement complex of southwestern Nigeria consists predominantly of gneisses, schists and quartzites with emplacement of granitic and basic rocks. Some of the basement rocks have been greatly weathered to form residual soils. In southwestern Nigeria, extensive occurrences of such residual bodies have been reported by various scientists. Emofurieta et, al. (1995) examined the secondary geochemical and mineralogical dispersion patterns associated with lateritization process in Ile-Ife, southwestern Nigeria. Kehinde-Phillips et. al. (1995) described the mineralogy and geochemistry of the weathering profiles over amphibolites, anthophylite and talc schists in the Ilesha schist belt, southwestern Nigeria. According to Bolarinwa (2006) examined the mineralogy and geochemistry of the weathering profiles above basement rocks in Ibadan and concluded that the weathering profiles are composed of quartz, kaolinite, goethite and limonite. Ige et al. (2005) studied the mineralogy and geochemistry of lateritic weathering profiles on ultramafic rock 
bodies around Mokuro in Ile-Ife area, southwestern Nigeria and observed that the weathering is towards lateritization. According to Adegbuyi et al. (2015), the weathered products in Akure, Isua-Akoko areas are predominantly clay materials. These clay deposits are kaolinitic clay and plastic kaolin and they are found to be very good raw materials for the industrial production of ceramics, paints and refractory, low alumina chemical pharmaceutical products and as additives in cement industry.

Investigation of weathered profiles reveals erratic variations in the major oxide composition and pronounced dissimulation in mineralogical characteristics in line with the parent rock and chemical environments. Hence, translocation and redistribution of the weathering products through groundwater and percolating rain water under appropriate $\mathrm{Eh}$ and $\mathrm{pH}$ conditions resulted in the lateritization or duricrust formation (Krauskopf, 1985).

Metallic ores and residual clays of economic values often occur within lateritic profiles above parent rocks in tropical regions due to supergene enrichment and leaching of labile components. Previous studies in Idi Ayunre and Akure district, were mainly on geochemistry of the basement rocks with little attention on the residual profiles over other rock types. The studying of the removal of mobile elements by meteoric water from the crystalline rocks, the resulted chemical variation along the profile and subsequent concentration of stable weathering products is the focus of present investigation

\section{Geologic Setting}

The basement rocks in Akure and Idi-Ayunre have been weathered to produce the residual soils. Ola (1983) defined lateritic soil as a residual soil derived essentially from chemical weathering of igneous and metamorphic rocks under tropical climate. During weathering, decomposition of rock and formation of soil occur simultaneously and are indistinguishable from each other. Thus, soil formation can be considered as an advanced stage of weathering. The unique characteristic of soil is the organization of its constituents and properties into layers that are related to the present-day surface and that change vertically with depth. Consequently the essential process in soil formation is the transportation of material from one level in the weathered debris to another resulting in different compositional horizons which may range in thickness from a few centimeters to several meters. The vertical sequence or soil profile generally comprises three principal horizons identified from the surface downward as A, B and C. A-horizon is the soil layer from which down-ward moving water has removed much of the soluble material, the B-horizon is the intermediate layer in which some of the soluble and colloidal materials are deposited and the C-horizon is the zone of fragmented but still largely unaltered rock that grades into underlying bedrock. Laterites commonly occur within the B-horizon below the top-soil. The parent rock, climate, topography, biological activity and time are the main factors that influence the development and the nature of a soil profile.

Idi-Ayunre and Akure areas lie in southwestern Nigeria (Figure1). The investigated residual profiles in Idi-ayunre are at the outskirt of Ibadan along the Abanla road. The areas of study are easily accessible due to the presence of secondary and primary roads, road cuts and recently blasted outcrops.

The major rock associations of Idi Ayunre and Akure areas are part of the Basement complex of Nigeria. Idi-Ayunre is underlain by banded gneiss and granite gneiss The minor rocks such as quartz vein and pegmatite occur as intrusions in the major rock types (Rahaman 1984). The entire western part of Idi-Ayunre is underlain by banded gneiss while the eastern part is predominantly made up of granite gneiss (Figure 2). Mineralogically, it is consisted of plagioclase, quartz, and biotite. Banded gneiss is strongly foliated and the foliation is defined by the alternation of mafic and felsic bands. The mafic bands contain mostly biotite while the felsic layer are made up of quartzofeldspartic minerals. The banded gneiss is highly susceptible to weathering due to its exposed planes of weakness.

According to Oyinloye (2007), Akure area is underlain by porphyritic granite, charnockite, banded gneiss and migmatite. (Figure 3) The porphyritic granite occurs mostly as massive outcrops around Oba-Ile area and along Owo road, Akure. It consists of phenocryst of feldspar mineral embedded in the matrix of feldspar and quartz. The felsic minerals consist of feldspar and quartz while the mafic mineral consists of biotite and other accessory minerals. The mafic minerals are randomly distributed within the porphyritic granite. The migmatite which is made up of leucocratic components alternating with basic components is located at the central part of Akure. The leucocratic component ranges from fine-grained granitic gneisses to medium grained banded gneisses especially around Shagari estate, Akure (Figure 3).

\section{Material and Methods}

Samples of rocks, clay, laterite and soil were obtained from fresh road cuts at specific intervals from top soil down to fresh basement rocks. Sixty samples comprising 15 each of top-soil, laterite, clay and rock were 
collected from three lateritic profiles above granite gneiss, migmatite, and porphyritic granite in the Idi-Ayunre and Akure areas. Petrographic study was carried out on thin sections of the rock samples. Clay, laterite and soil mineralogy was determined using X-ray Diffraction (XRD) at Activation Laboratory in Canada. The X-ray diffraction analysis was performed on a Panalytical X'Pert Pro diffractometer, equipped with a $\mathrm{Cu} X$-ray source and an X'celerator detector, operating at the following conditions: voltage - $40 \mathrm{kV}$; current - $40 \mathrm{~mA}$; range - 5-80 ${ }^{\circ} 2 \theta$; step size: $0.017,{ }^{\circ} 2 \theta$; time per step: $50 \mathrm{~s}$; divergence slit: fixed, angle $0.5^{\circ}$. The crystalline mineral phases were identified by X'Pert HighScore Plus software using the PDF-4 ICDD database. The quantities of the crystalline minerals were determined using the Rietveld method. The Rietveld method is based on the calculation of the full diffraction pattern from crystal structure information. Elemental compositions of the rocks and clay samples were determined using Inductively Coupled Plasma-Mass Spectrometer (ICP-MS) at Activation Laboratory, Canada . For ICP-MS, microwave high pressure/temperature decomposition of samples $\left(230^{\circ} \mathrm{C}\right.$, 7.0MPa; Paar Physical Multiwave sample preparation system) using Merck Suprapurs grade reagents (HF, $\mathrm{HCIO}_{4}, \mathrm{HNO}_{3}$ and $\mathrm{HCl}$ ). All measurements were made on a Sciex/Perkin-Elmer ELAR 6000 ICP-MS. The Chemical Index of Alteration ( $\left.\mathrm{CIA}=\mathrm{Al}_{2} \mathrm{O}_{3} / \mathrm{Al}_{2} \mathrm{O}_{3}+\mathrm{CaO}+\mathrm{Na}_{2} \mathrm{O}+\mathrm{K}_{2} \mathrm{O}\right) \mathrm{X} 100$, where all components expressed in molecular proportions was calculated to measure the Intensity of Chemical Weathering (ICW) of soils.

\section{Results and Discussion}

\subsection{Field Work and Macro-Petrography}

Profile 1 is located above the banded gneiss at Idi- Ayunre via Ibadan. A $6 \mathrm{~m}$ thick profile over banded gneiss is exposed in a quarry and is essentially residual. The presence of relic structures of parent rock and angular quartz grains in the profile strongly supported its insitu nature. There is no evidence of large scale movement of weathered materials. Four distinct layers were identified based on colour, texture along with relic structures in the saprolitic zone. It is noticed on the field that the color gets brownish towards the top. (Figure4a)

The upper horizon which is the topsoil is generally light brown in colour and is about $0.2 \mathrm{~m}$ thick. It contains rootlet of plants and is characterized by the presence of organic matter (humus). This layer is friable and contains some pebbles of quartz. Below this layer is a reddish and partly consolidated laterite which is about $1.2 \mathrm{~m}$ thick. The lateritic layer grades gradually into the underlying clayey horizon. In this layer, the organic content has almost completely disappeared. The clay layer is underlain by saprolitic zone characterized by some whitish and reddish spots and this graded into the bedrock.

Profile 2 is located above porphyritic granite in Akure. A $7 \mathrm{~m}$ thick profile was exposed around Fiwasaye Girls Grammar School, Akure (Figure 4b). The weathering profile over granite gneiss consists of four distinct layers. The layers are characterized based on their texture, colour and relic structures in the saprolitic zones. The topsoil layer is dark grey in colour and is about $0.3 \mathrm{~m}$ thick. It contains rootlets of plants, organic matter, decomposed leaves and angular quartz pebbles. Below this horizon is a reddish brown laterite with a thickness of about $3 \mathrm{~m}$,organic matter has completely disappeared. Laterite grades gradually into the clay layer which is about $3 \mathrm{~m}$ thick. The clay horizon is brownish in colour and organic material in this layer has disappeared completely. The saprolite characterized by relic structures grades to the fresh parent rock. The fresh bedrock could not be reached due to the thickness of the weathered profile.

Profile 3 is located above migmatite gneiss opposite the Federal University of Technology Akure (FUTA). A 10m thick profile was exposed at the back of the filling station about it is about $300 \mathrm{~m}$ opposite the FUTA second gate. (Figure 4c). In the field, there is no evidence of soil movement or transportation, hence, they are in-situ. Three layers are recognized and they are characterized by their different colours and textures. The upper layer is dark grey in colour and it is about $0.5 \mathrm{~m}$ thick, it contains rootlets of plants and angular pebbles of quartz which proves that the profile is residual. The topsoil grades gradually into the underlying reddish brown laterite which is about $3 \mathrm{~m}$ thick. Laterite grades gradually into clay horizon which is brown in color with an average thickness of $8 \mathrm{~m}$. It is noticed on the field that the clay gets finer towards the bottom and shows colour laminations of the mineralogical banding of the parent rock. The basement rock could not be reached due to thick overburden.

\subsection{Mineralogy}

The X-ray diffractograms of soil, laterite and clay on the banded gneiss are shown in Figure 5. Conspicuous peaks of quartz, microcline and albite are recorded by the X-ray chart of the soil sample (Figure 5), while quartz, kaolinite and goethite are the major minerals reflected in the difractograms of the laterite and clay. Quartz is apparently present in all the profiles because of its high resistance to weathering. Biotite and other ferromagnesian minerals in the fresh rock have probably weathered to generate kaolinite in the laterite. While microcline which is present in the soil has also altered by chemical weathering to kaolinite and equally leached 
into laterite horizon.

On the migmatite gneiss, only the peaks of quartz, microcline and albite are recorded by the X-ray chart of the soil sample. The presence of microcline and albite show that weathering is still at incipient stage (Figure 6), while quartz, kaolinite and goethite are the major minerals reflected in the diffractograms of the laterite and kaolinite and quartz dominated the clay charts.

The X-ray diffractograms on the porphyritic granite show that the soil is predominantly made of quartz and kaolinite, microcline, albite. Kaolinite and quartz are the major minerals reflected in the diffractograms of the laterite, while kaolinite and quartz dominated the clay charts (Figure 6).

\subsection{Chemical Compositions}

The average chemical data of weathering profile over banded-gneiss at Idi-Ayunre are presented in Table 1 . The Table shows the concentrations of major and trace elements of banded gneiss. The average compositions of $\mathrm{SiO}_{2}$ are $66.04 \%, 59.25 \%, 57.74 \%$ and $67.05 \%$ in the parent rock, clay, laterite and soil respectively. This shows that relative to parent rock, there has been depletion in the $\mathrm{SiO}_{2}$ in the weathering profile (Figure8). The enhanced value of $67.05 \%$ in the top soil may be due to relative depletion of $\mathrm{MnO}, \mathrm{MgO}, \mathrm{CaO}, \mathrm{Na}_{2} \mathrm{O}$ and $\mathrm{K}_{2} \mathrm{O}$ in the soil horizon. Hence, free quartz, $\mathrm{SiO}_{2}$ is present in silicate minerals and their weathering and dissolution apparently led to the enrichment of $\mathrm{SiO}_{2}$ and $\mathrm{Fe}_{2} \mathrm{O}_{3}$ in the top soil. The average concentration values of $\mathrm{Al}_{2} \mathrm{O}_{3}$ increase from $15.85 \%$ in the parent rock to $22.53 \%$ in the clay with $24.63 \%$ in laterite and slightly reduced to $17.21 \%$ in the top soil. This indicates that there is a significant enrichment of $\mathrm{Al}_{2} \mathrm{O}_{3}$ in the clay and laterite profile compared to the parent rock (Figure 8). From the chemical data, the relative enrichment could be explained by the removal of $\mathrm{MgO}$ and weathering of $\mathrm{Al}_{2} \mathrm{O}_{3}$ bearing minerals such as biotite in the banded-gneiss. $\mathrm{Fe}_{2} \mathrm{O}_{3}$ has average of $4.10 \%$, $4.72 \%, 6.73 \%$ and $7.79 \%$ in the parent rock, clay, laterite and soil respectively. This indicates a strong enrichment of $\mathrm{Fe}_{2} \mathrm{O}_{3}$ in the weathering profile relative to the parent rock. This is typical for the weathering and lateritization of felsic rocks. The values of the average $\mathrm{Fe}_{2} \mathrm{O}_{3}$ concentration show that the iron bearing minerals such as biotite in the parent rock have probably been affected by chemical weathering to release iron oxides/hydroxide in the weathering horizons (Kehinde-Phillips et al. 1995). The values of $\mathrm{CaO}, \mathrm{Na}_{2} \mathrm{O}, \mathrm{K}_{2} \mathrm{O}$, $\mathrm{P}_{2} \mathrm{O}_{5}$ and $\mathrm{MnO}$ and reduce up the profile indicating strong leaching. The progressive dissolutions and mobility of $\mathrm{Mg}, \mathrm{Ca}, \mathrm{K}, \mathrm{Na}$ led to their depletions in the weathering profiles (Aleva 1994, Kehinde-Philips 1991, Bolarinwa 2006).

Trace element data in Table 1 show enhancement of $\mathrm{Ba}, \mathrm{Zr}, \mathrm{Y}, \mathrm{Sc}$ in clay, laterite and soil compared to the parent rock, however, $\mathrm{Sr}$ is depleted from 780 to $363 \mathrm{ppm}$ in clay subsequently being reduced to $115 \mathrm{ppm}$ in laterite. The silica-sequioxide ratio (S.R) of the rock (3.31), clay (3.35), laterite (2.04), soil (2.22) are stated in Table (1), the alumina-iron (A.R) are (3.86), (4.77), (6.60), (6.17) for rock, clay, laterite and soil. The relatively high S.R and A.R strongly suggest that true laterites are produced from the weathering of iron bearing minerals in the banded gneiss (Aleva, 1994). The total values of $(\mathrm{MgO}+\mathrm{CaO})$ are 6.33 in the rock and $1.05,0.71$ and 1.73 in the clay, laterite and soil respectively while the total values of $\left(\mathrm{Na}_{2} \mathrm{O}+\mathrm{K}_{2} \mathrm{O}\right)$ is 5.21 in the rock, $0.93,5.39$ and 4.85 in clay, laterite and soil. Relatively high $\mathrm{Na}_{2} \mathrm{O}$ and $\mathrm{K}_{2} \mathrm{O}$ are mainly contributed by the weathered plagioclase and muscovite minerals while low $\mathrm{MgO}$ and $\mathrm{CaO}$ is probably due to the low amount of mafic minerals in the parent rock, this trend observed is similar to the granite gneiss at Ibadan area by Bolarinwa 2001

The average concentrations of major and trace elements in the weathering profile over migmatite are presented in Table 2. The average compositions of $\mathrm{SiO}_{2}$ are $68.49 \%, 47.43 \%, 42.64 \%$ and $44.37 \%$ in the parent rock, clay, laterite and soil respectively. This shows that relative to the parent rock, there has been depletion in the $\mathrm{SiO}_{2}$ in the weathering profile. The average concentration values of $\mathrm{Al}_{2} \mathrm{O}_{3}$ increase from $15.53 \%$ in the parent rock to $36.01 \%$ in the clay with $28.59 \%$ in laterite. This indicates that there is a significant enrichment of $\mathrm{Al}_{2} \mathrm{O}_{3}$ in the clay and laterite profile compared to the parent rock. Such enrichment could be explained by the removal of $\mathrm{MgO}$ and weathering of $\mathrm{Al}_{2} \mathrm{O}_{3}$ bearing minerals such as biotite in the migmatite gneiss (Figure 9). $\mathrm{Fe}_{2} \mathrm{O}_{3}$ has average of $2.85 \%, 2.46 \%, 15.03 \%$ and $14.25 \%$ in the parent rock, clay, laterite and soil respectively. This indicates strong enrichment $\mathrm{Fe}_{2} \mathrm{O}_{3}$ in the weathering profile relative to the parent rock. This is typical of the weathering and lateritization of felsic rocks. The values of the average $\mathrm{Fe}_{2} \mathrm{O}_{3}$ concentration show that the iron bearing minerals (e.g biotite) in parent rock have probably been affected by chemical weathering to release iron oxides/hydroxide in the weathering horizons.

The depletion of $\mathrm{MgO}, \mathrm{CaO}, \mathrm{Na}_{2} \mathrm{O}, \mathrm{K}_{2} \mathrm{O}, \mathrm{P}_{2} \mathrm{O}_{5}$, and $\mathrm{MnO}$ are particularly pronounced and they are removed at a faster rate. The corresponding values for $\mathrm{MgO}$ are $1.18 \%, 0.05 \%, 009 . \%$ and $0.02 \% \mathrm{CaO}$ are $4.34 \%, 0.01 \%, 0.02 \%$ and $0.37 \%, \mathrm{Na}_{2} \mathrm{O}$ are $4.95 \% 0.01 \%, 0.01 \%, 0.02 \%, \mathrm{~K}_{2} \mathrm{O}$ are $1.31 \%, 0.03 \%, 0.53 \%, 0.21 \%, \mathrm{P}_{2} \mathrm{O}_{5}$ are $0.14 \%, 0.05 \%$ $0.09 \%, 0.19 \%, \mathrm{MnO}$ are $0.05 \%, 0.01 \%, 0.01 \%, 0.14 \%, \mathrm{Cr}_{2} \mathrm{O}_{3}$ are $0.23 \%, 0.02 \%, 0.07$ in the rock, clay, laterite 
and soil respectively. This progressive dissolutions and mobility of magnesium, calcium, potassium, sodium has led to their depletions in the weathering profiles (Kehinde - Philips 1995, Bolarinwa 2006). According to Aleva (1994), the decrease in $\mathrm{CaO}, \mathrm{Na}_{2} \mathrm{O}, \mathrm{K}_{2} \mathrm{O}, \mathrm{P}_{2} \mathrm{O}_{5}, \mathrm{MnO}$ and $\mathrm{Cr}_{2} \mathrm{O}_{3}$ contents of the weathering profiles relative to the parent rock is due to leaching of these oxides.

Trace element data in Table 2 show enhancement of $\mathrm{Zr}, \mathrm{Y}, \mathrm{Sc}$ in clay, laterite and soil compared to the parent rock, however, in $\mathrm{Ba}$ and $\mathrm{Sr}$ exhibit depletion. The silica-sequioxide ratio (S.R) of the rock 3.77 , clay 1.22, laterite 0.99 , soil 1.23 are stated in table (2) the alumina-iron (A.R) are 5.39, 14.63, 1.90, 1.59 for rock, clay, laterite and soil respectively. The relatively high S.R and A.R strongly suggest that true laterites are produced from the weathering of iron bearing minerals in the pegmatite (Aleva, 1994). The total values of alkalis (MgO + $\mathrm{CaO})$ are 5.52 in the rock and $0.06,0.11$ and 0.06 in the clay, laterite and soil respectively while the total values of $\left(\mathrm{Na}_{2} \mathrm{O}+\mathrm{K}_{2} \mathrm{O}\right)$ is 6.26 in the rock, $0.44,0.06$ and 0.26 in clay, laterite and soil. The silica- sequioxide ratio has been used to quantify the degree of weathering and lateritization (Martins and Doyne, 1927).

The average concentrations of major and trace elements in the weathering profile over porphyritic granite at Akure are presented in Table 3. The mean compositions of $\mathrm{SiO}_{2}$ are $68.86 \%, 50.11 \%, 46.47 \%$ and $50.12 \%$ in the parent rock, clay, laterite and soil respectively. This shows that relative to the parent rock, there has been depletion in the $\mathrm{SiO}_{2}$ in the weathering profile. The enhanced value of $50.12 \%$ in the top soil may be due to relative depletion of $\mathrm{MnO}, \mathrm{MgO}, \mathrm{CaO}, \mathrm{Na}_{2} \mathrm{O}, \mathrm{K}_{2} \mathrm{O}$, in the soil horizon. Hence, apart from the occurrence of free quartz, $\mathrm{SiO}_{2}$ is present in silicate minerals such as biotite, amphiboles and pyroxene. The weathering and dissolution of these silicate minerals apparently led to the enrichment of $\mathrm{SiO}_{2}$ and $\mathrm{Fe}_{2} \mathrm{O}_{3}$ in the top soil. The average concentration values of $\mathrm{Al}_{2} \mathrm{O}_{3}$ increase from $15.39 \%$ in the parent rock to $32.32 \%$ in the clay with $28.95 \%$ in laterite. This indicates that there is a significant enrichment of $\mathrm{Al}_{2} \mathrm{O}_{3}$ in the clay and laterite profile compared to the parent rock. From the chemical data, the relative enrichment could be explained by the removal of $\mathrm{MgO}$ and weathering of $\mathrm{Al}_{2} \mathrm{O}_{3}$ bearing minerals such as biotite in the pegmatite. $\mathrm{Fe}_{2} \mathrm{O}_{3}$ has average weight percentage of $3.3 \%, 3.45 \%, 10.02 \%$ and $8.34 \%$ in the parent rock, clay, laterite and soil respectively. This indicates strong enrichment $\mathrm{Fe}_{2} \mathrm{O}_{3}$ in the weathering profile relative to the parent rock. This is typical of the weathering and lateritization of felsic rocks. The corresponding values for $\mathrm{CaO}$ are $3.38 \%, 0.02 \%, 0.03 \%$ and $0.33 \%, \mathrm{Na}_{2} \mathrm{O}$ are $3.15 \% 0.01 \% 0.02 \%, 0.18 \%, \mathrm{~K}_{2} \mathrm{O}$ are $1.75 \%, 0.37 \%, 0.58 \%, 2.28 \%, \mathrm{P}_{2} \mathrm{O}_{5}$ are $0.14 \%, 0.09 \% 0.34 \%, 0.20 \%$, MnO are $0.05 \%, 0.01 \%, 0.02 \%, 0.08 \% \mathrm{Cr}_{2} \mathrm{O}_{3}$ are $0.01 \%, 0.01 \%, 0.007 \%$ in the rock, clay, laterite and soil respectively. This progressive dissolutions and mobility of magnesium, calcium, potassium, sodium has led to their depletions in the weathering profiles (Kehinde - Philips 1995, Bolarinwa 2006). According to Aleva (1994), the decrease in $\mathrm{CaO}, \mathrm{Na}_{2} \mathrm{O}, \mathrm{K}_{2} \mathrm{O}, \mathrm{P}_{2} \mathrm{O}_{5}, \mathrm{MnO}$ and $\mathrm{Cr}_{2} \mathrm{O}_{3}$ contents of the weathering profiles relative to the parent rock is due to leaching of these oxides. Trace element data in Table 3 show enhancement of $\mathrm{Sr}, \mathrm{Zr}, \mathrm{Y}, \mathrm{Sc}$ in clay, laterite and soil compared to the parent rock. As stated in Table 3, the silica-sequioxide ratio (S.R) of the rock, clay, laterite and soil are $7.84 \%, 1.80 \%, 1.19 \%, 1.80 \%$ respectively while alumina-iron (A.R) are $4.63 \%, 9.32 \%, 2.60 \%, 2.69 \%$ for rock, clay, laterite and soil. The relatively high S.R and A.R strongly suggest that true laterites are produced from the weathering of iron bearing minerals in the migmatite gneiss (Aleva, 1994). The total values of (MgO + $\mathrm{CaO}$ ) are $4.45 \%$ in the rock and $2.47 \%, 0.60 \%$ and $2.47 \%$ in the clay, laterite and soil respectively while the total values of $\left(\mathrm{Na}_{2} \mathrm{O}+\mathrm{K}_{2} \mathrm{O}\right)$ is $6.06 \%$ in the rock, $0.59 \%, 0.12 \%$ and $0.59 \%$ in clay, laterite and soil. This is similar to the trend observed in banded gneiss and migmatite.

\section{Mineralogical and Geochemical Trends in the Soil.}

Weathering of banded gneiss, porphyritic granite, and migmatite in Idi-Ayunre and Akure areas resulted in the formation of soil layer $(0-0.5 \mathrm{~m})$, laterite layer $(0.9-1.8 \mathrm{~m})$, and clayey zone $(3.9-7.6 \mathrm{~m})$. The maximum depth of the profile observed in the field is $10 \mathrm{~m}$.

The rocks samples are grey or light coloured due to their felsic nature. Petrographic study carried out on thin sections showed that quartz, plagioclase feldspars, and biotite were the essential minerals in the granitic rocks Whole rock mineralogy determined using the X-ray diffraction showed that quartz and kaolinite were the dominant minerals in the decomposed rocks. In most of the soil horizon, prominent peaks of quartz, kaolinite and microcline were recorded while kaolinite, quartz, and goethite peaks are more conspicuous in the laterite layer. The concentration of goethite in the laterite horizon supported leaching from the top-soil and supergene enrichment of the iron oxides in the underlying laterite horizon (Kehinde-Phillips 1995). The clayey zone, which is $3.9 \mathrm{~m}, 4.8 \mathrm{~m}$ and $8 \mathrm{~m}$ thick on banded gneiss, porphyritic granite and migmatite respectively, showed conspicuous peaks of kaolinite. Bauxite mineral (gibbsite) was conspicuously absent in the profile, the trend of weathering in all the profiles is towards iron enrichment (ferralitization) rather than aluminium accumulation (bauxitization). 
The general trend in all the profile is a decrease in $\mathrm{SiO}_{2}$ content from bedrock to the lateritic zone. Loss of silica up the profiles on granitic rocks could be due to the break down of silicate minerals due to weathering and leaching of silica as silicic acid $\mathrm{SiO}(\mathrm{OH})_{2}$, in the solution along with $\mathrm{Ca}, \mathrm{Na}, \mathrm{K}$ and $\mathrm{Mg}$. The $\mathrm{Fe}_{2} \mathrm{O}_{3}$ content increased from the bedrock to the lateritic zone due to free ions produced during weathering which combined with air and water to form oxide or hydroxide. The increase could also be due to the development of clay complexes from intense weathering of feldspar to form clay. It could also result from hydration of hematite near the surface to produce hydrate iron oxide or hydrate limonite $\left[\mathrm{FeO}(\mathrm{OH}) \cdot \mathrm{nH}_{2} \mathrm{O}\right]$, which formed a secondary coating in most soil particles. This is similar to the trends reported in the weathering profiles of Older granite and granite gneiss in Ibadan, Abeokuta, Ilesha and Ile-Ife areas (Emofurieta et al., 1995, Ige et. al. 2005 Bolarinwa, 2006). The $\mathrm{Na}_{2} \mathrm{O}, \mathrm{K}_{2} \mathrm{O}, \mathrm{CaO}, \mathrm{P}_{2} \mathrm{O}_{5}$ content increased down the profile from the lateritic zone to the bedrock. Decrease in their concentrations upward towards A horizon is due to decomposition of silicate minerals (feldspar) during weathering to form clay minerals and leaching of these elements.

Chemical Index of Alteration (CIA) $=\mathrm{AL}_{2} \mathrm{O}_{3} / \mathrm{AL}_{2} \mathrm{O}_{3}+\mathrm{CaO}+\mathrm{Na}_{2} \mathrm{O}+\mathrm{K}_{2} \mathrm{O}$ ) X 100, where all components expressed in molecular proportions is commonly used as a measure of the Intensity of Chemical Weathering (ICW) of soils. (This parameter was derived by Nesbitt and Young 1982, 1984). Nesbitt and Young (1984), indicated that CIA values of 30 to 55 is an indication of weathering at incipient zone, while CIA values ranging from 51 to 85 could be considered as intermediate zone of weathering. Weathering that is at the advanced stage will have CIA values greater than 85 . Tables 1,2 and 3 show the summary of the average values of the calculated Chemical Index of Alterations (CIA) for the different weathering profiles in Idi-Ayunre and Akure areas. Based on the CIA values recorded in Tables, it is observed that all weathered profiles have experienced moderate to high intensity of chemical weathering. The average CIA values of banded gneiss are 57.13 and 81.39 for rock and laterite respectively. These values showed increasing trends of weathering that have reached the moderate stage. The average values of CIA of migmatite are 51.05, 99.29, 99.72 and 98.36 in the rock, clay, laterite and soil respectively while, the CIA values for porphyritic profile from rock to weathered layers, varied from 59.11 (rock) to 97.20 (laterite). The values show progressive chemical weathering that has reached a matured stage with high intensity in the Akure area (Figure 11), this is similar to the intensity of weathering in gneissic rocks observed by Nesbitt and Young, (1984) and Anuspam and Rajamani, (1999). The clay mineralogy and CIA values of banded gneiss, migmatite and porphyritic granite showed that nearly all the primary minerals have decomposed to form secondary minerals such as kaolinite. This trend is similar to the weathering of the Ife, Ibadan and Abeokuta banded and granitic rocks by Emorforieta et al. (1995), Kehinde-Phillips and Tietz (1995) and Bolarinwa and Elueze (2004).

The silica to sequioxide (S.R) ratio is used to determine the types of soil formed from the chemical weathering of the parent rocks. True laterite is assigned a ratio of 1.33; lateritic soil 1.33 to 2.0 and non lateritic if the value is greater than 2.00 (Nesbitt and Young 1984, 1989, Adeyemi and Ogundero 2001, Ola 1982 and Martin and Doyen 1927). Results from Tables 1, 2 and 3 showed that laterites above migmatite and porphyritic granite with average S.R of 0.99 and 1.19 can be categorized as true laterite. The soils formed from banded gneiss with S.R ratios of 2.04 are non lateritic soils due to their high S.R values.

The ternary plots of $\mathrm{SiO}_{2}-\mathrm{Al}_{2} \mathrm{O}_{3}-\mathrm{Fe}_{2} \mathrm{O}_{3}$ (Gardner and Walsh 1996) of the different profiles showed that the trend of weathering inclines towards lateritization rather than bauxitization (Figure 12). The dominance of iron bearing minerals such as goethite $\mathrm{n}$ the lateritic profiles and the high $\mathrm{Fe}_{2} \mathrm{O}_{3}$ content in their geochemical data proved that the weathering is towards iron enriching (ferralitization) rather than aluminum accumulation (bauxitization).

\section{Conclusions}

Lateritization is the dominant process of chemical weathering in tropical and subtropical regions of the world. This present case-study reveals that the weathering of banded gneiss, migmatite, and porphyritic granite has reached advanced stage and the dominance of iron bearing minerals in the lateritic profiles shows that the weathering is towards lateritization rather than bauxitization. The leaching process involving the alkali and alkali earth metals resulted in a residue enriched in quartz, Fe-oxides and kaolinite clays which vary in proportion along the profiles. This study also shows that laterites above migmatite and porphyritic granite can be categorized as true laterite while the soils formed from banded gneiss are non lateritic soils due to their high S.R values

\section{Acknowledgement}

The authors wish to acknowledge the Geology Department of Crawford University for permission to use the laboratory for petrographic analyses.. 


\section{References}

Adegbuyi, O., Ojo, G. P., Adeola, A. J., \& Alebiosu, M. T. (2015) Compositional and industrial assessment of Isua Akoko, Akure. Ayadi and Ode Aye clay deposits of Ondo State, Nigeria. Global Journal of Pure and Applied Sciences, 21, 38-46

Adeyemi, G. O. (1992). Highway geotechnical properties of laterised residual soils in the Ajebo-Ishara geological transition zone of southwestern Nigeria. Unpublished Ph.D Thesis. Department of Geology, Obafemi Awolowo University, Ile - Ife, Nigeria.

Adeyemi, G. O., \& Ogundero, O. C. (2001). Some Geotechnical properties of soil developed over migmatite-gneiss in Oru-Ijebu, southwestern Nigeria. Journal of Applied Sciences. 4(3) 2130-2150. Aleva, G.J. 1994. Laterites; Concepts, Geology, Morphology and Chemistry, ISRIC, Wageningen. 169p

Anupam S., \& Rajamani, V. (2000). Weathering of gneissic rocks in the upper reaches of Cauvery river, south India: Implications to neotectonics of the region. Chemical Geology, 166, 203-223.

Bolarinwa, A. T. (2006). Mineralogy and geochemistry of the weathering profiles above basement rocks in Ibadan, southwestern, Nigeria. Global Journal of Geological Sciences, 4(2), 183-191.

Bolarinwa, A. T. (2001). Compositional characteristics and economic potentials of the lateritic profiles over basement and sedimentary rocks in Ibadan-Abeokuta area, southwestern Nigeria, Unpublished Ph.D. Thesis, University of Ibadan. 255p.

Elueze, A. A., \& Bolarinwa, A. T. (1994). Assessment of function, application of lateritic clay bodies in Ekiti environs, south western Nigeria. Journal of Mining and Geology, 31, 79-83.

Elueze, A. A., Ekengele, N. L., \& Bolarinwa, A. T. (2004). Industrial assessment of the residual clay bodies over gneisses and schists of Younde area, southern Cameroon. Journal of Mining and Geology, 40(1), 9-15.

Emofurieta, W. O., Ogundimu. T. O., \& Imeokparia, E. G. (1944): Mineralogical, Geochemical and Economic Appraisal of some clay and shale deposits in Southwestern and northeastern Nigeria. Jour. Mineral. Geol., 30(2), 151-159.

Gardner, R., \& Walsh, N. (1996). Chemical weathering of metamorphic rocks from low elevations in southern Himalaya. Chemical Geology, 127, 161-176.

Ige, O. A., Durotoye, B., \& Oluyemi, A. E. (2005). Mineralogy and geochemistry of lateritic weathering profiles on ultramafic rock bodies around Mokuro in Ile-Ife area, southwestern Nigeria. Journal of Mining and Geology, 41(1), 11-18.

Kehinde-Phillips, O. O. (1991). Compositional variations within laterite profiles over mafic and ultramafic rock units of the Ilesha schist belt, Southwestern Nigeria PhD. Thesis university of Ibadan, Unpubl $201 \mathrm{p}$.

Kehinde-Phillips, O. O., \& Tietz, G. F. (1995). The mineralogy and geochemistry of theweathering profiles over amphibollite and Talk-schists in the Ilesha scist belt, southwestern. Nigeria Journal of Mining and Geology, 31(1), 53-62.

Martins, F. J., \& Doyne, F. C. (1927): Laterite and lateritic soils in Sierra Leone. Int. Jour, Agric sci., 17, 530-55.

Nesbitt, H. W., \& Young, G. M. (1984). Prediction of some weathering trends of plutonic and volcanic rocks based on thermodynamic and kinetic. Geochim. Cosmochin. Acta, 48, 1523-1534.

Ola S. A. (1982). Geotechnical properties and behavior of some Nigeria lateritic soils. In Ola S.A. (Ed), Tropical soils of Nigeria in Engineering Practice (pp. 61-63).

Oyinloye, O. A. (2007). Geology and geochemistry of some crystalline besement rocks in Ilesha area, southwestern Nigeria: Implications on provenance and evolution. Pakistan Journal of Scientific and Industrial Research, 50(4), 233-231.

Rahaman, M. A. (1984). Recent advances in the study of the basement complex of Nigeria. In Oluyide P.O. et al. (Eds.), Precambrian Geology of Nigeria (pp 241-256). 


\section{Appendix}

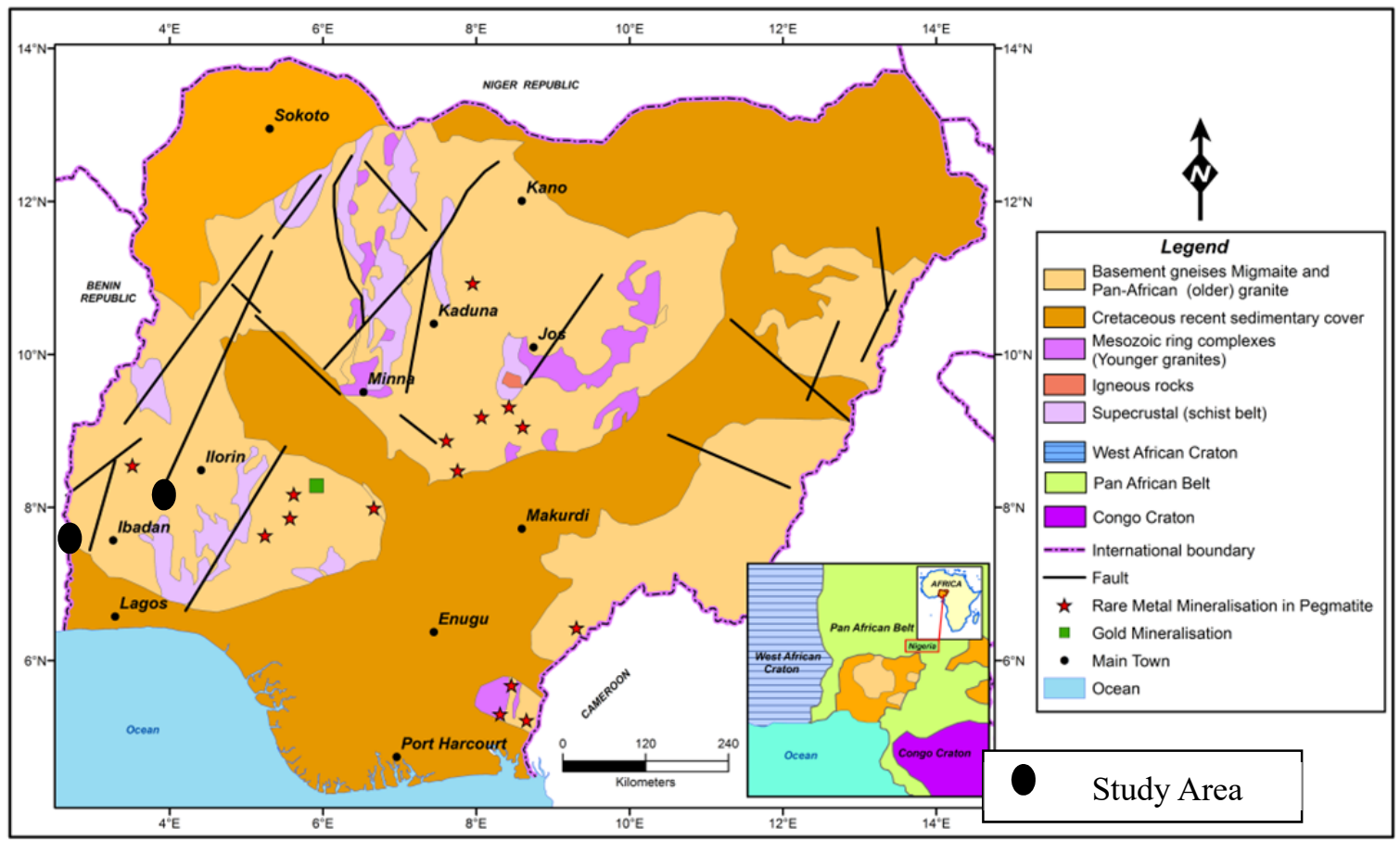

Figure 1. Map of Nigeria showing the location of the study area

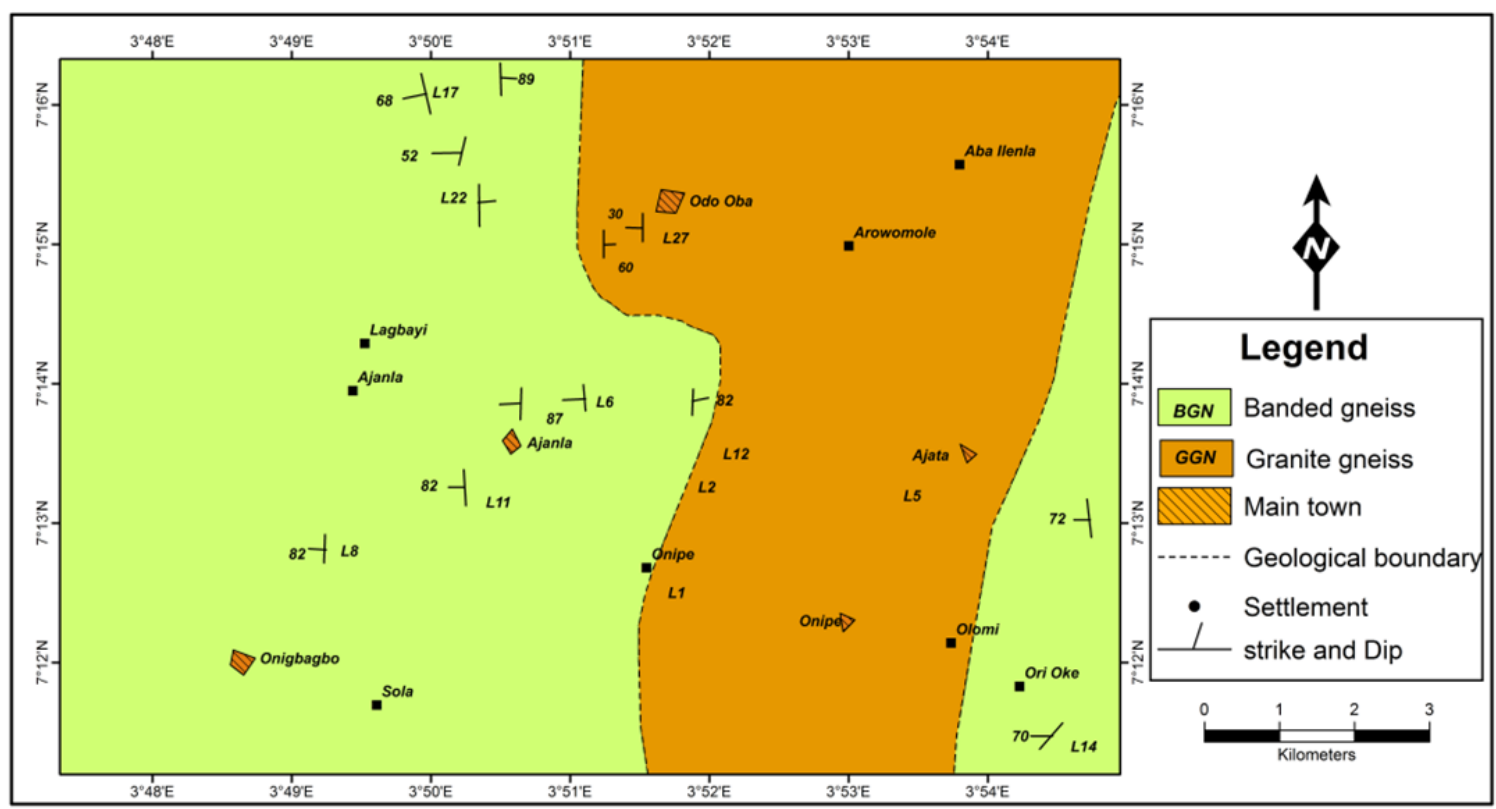

Figure 2. Geological map of Idi-Ayunre area and its' environs 


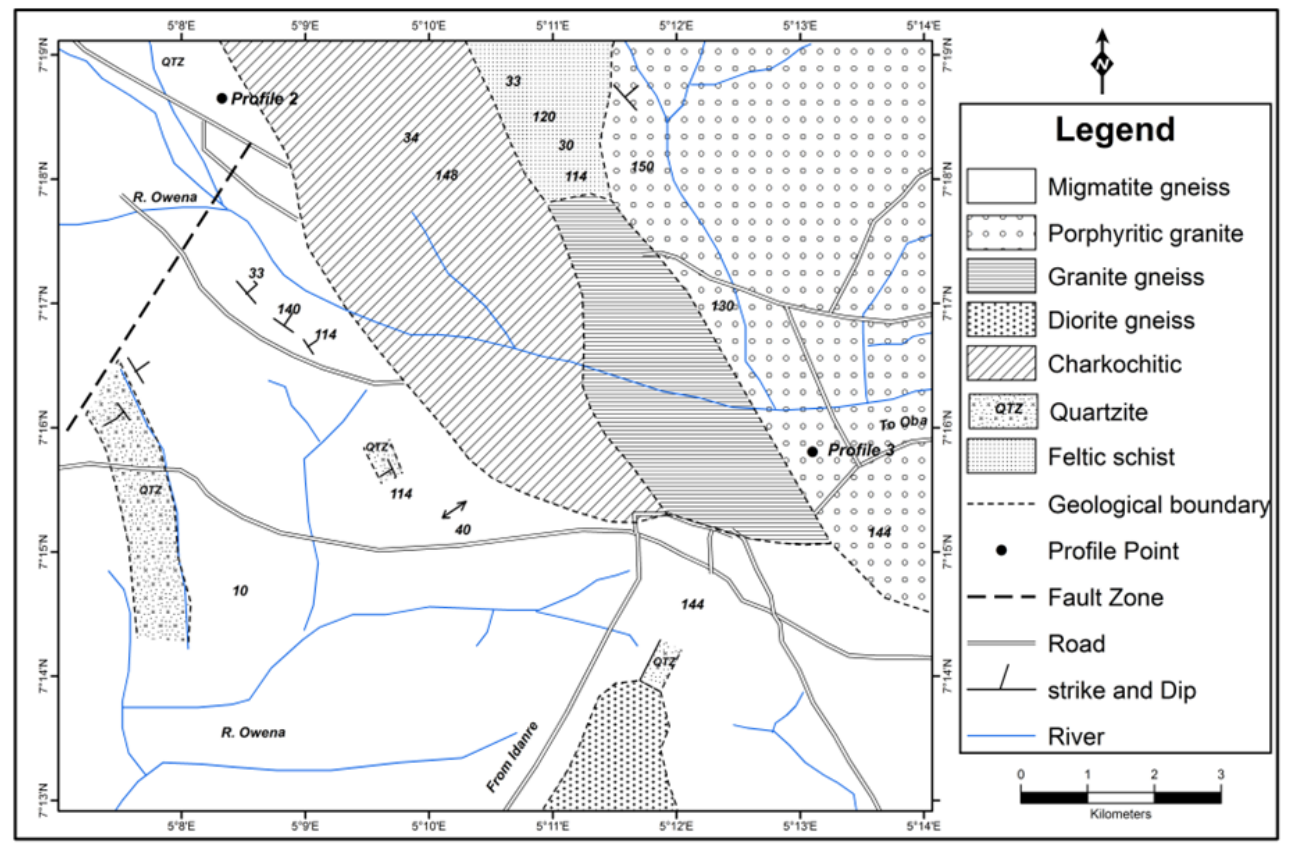

Figure 3. Geologic map of Akure and its' environs

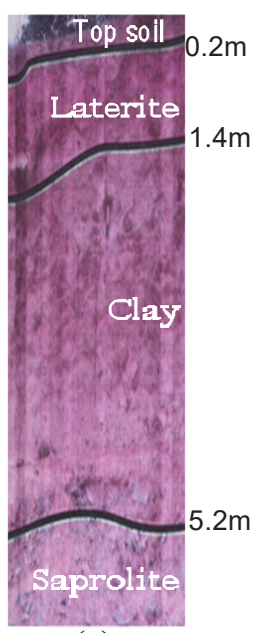

(a)

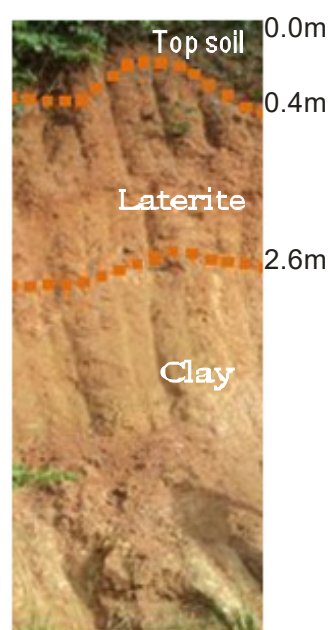

(b)

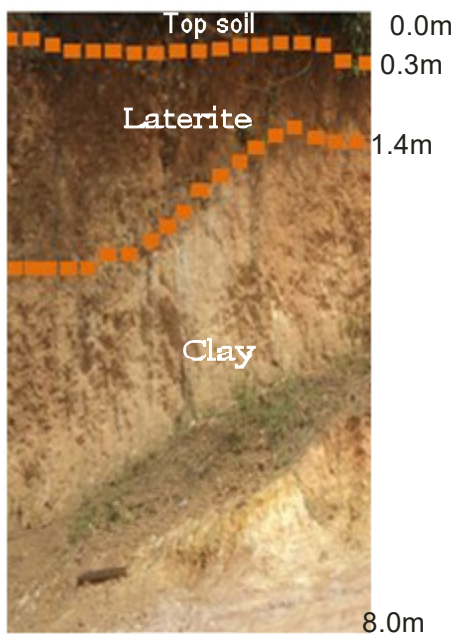

(c)

Figure 4. Weathering profiles of the study areas
(a)- Idi-Ayunre
(b)-Akure,
(c)- Akure 


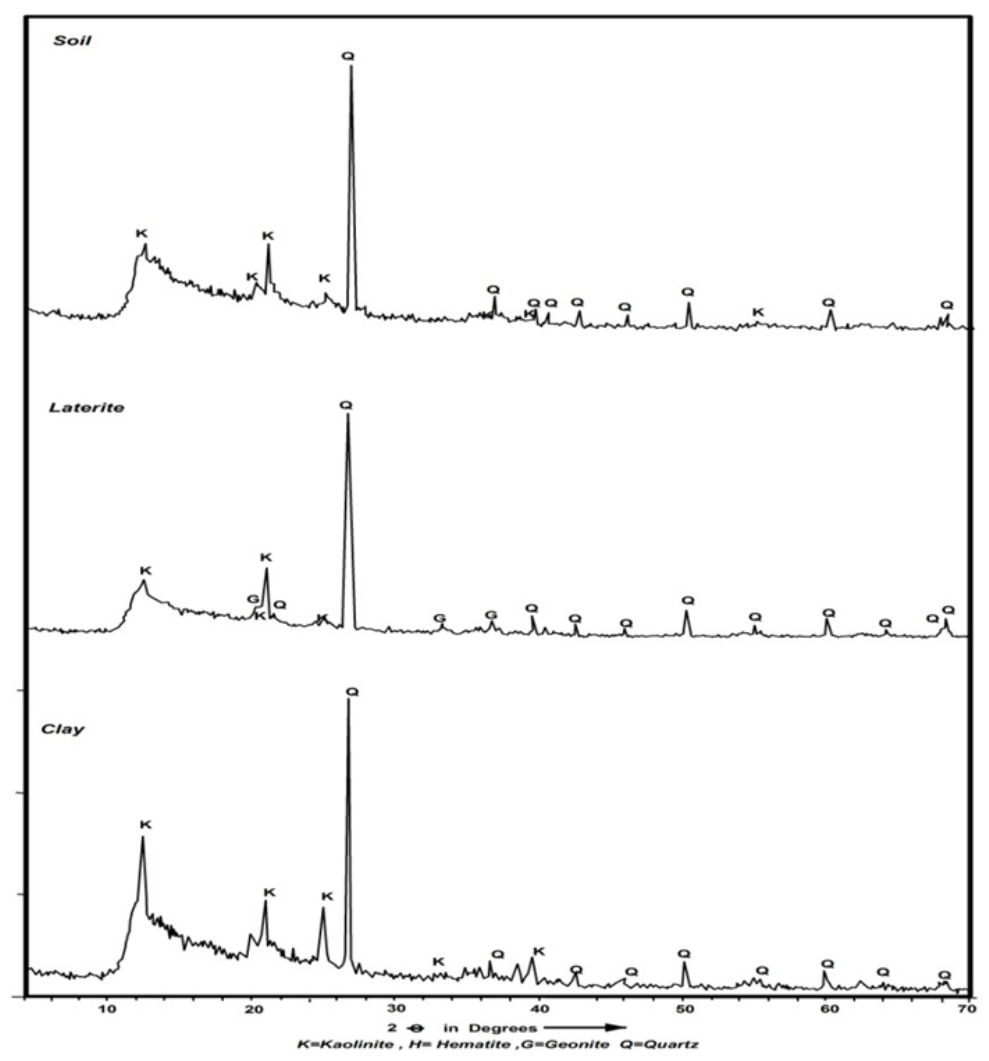

Figure 5. X-ray diffractograms of the weathered profiles above banded gneiss at Idi-Ayunre, Ibadan

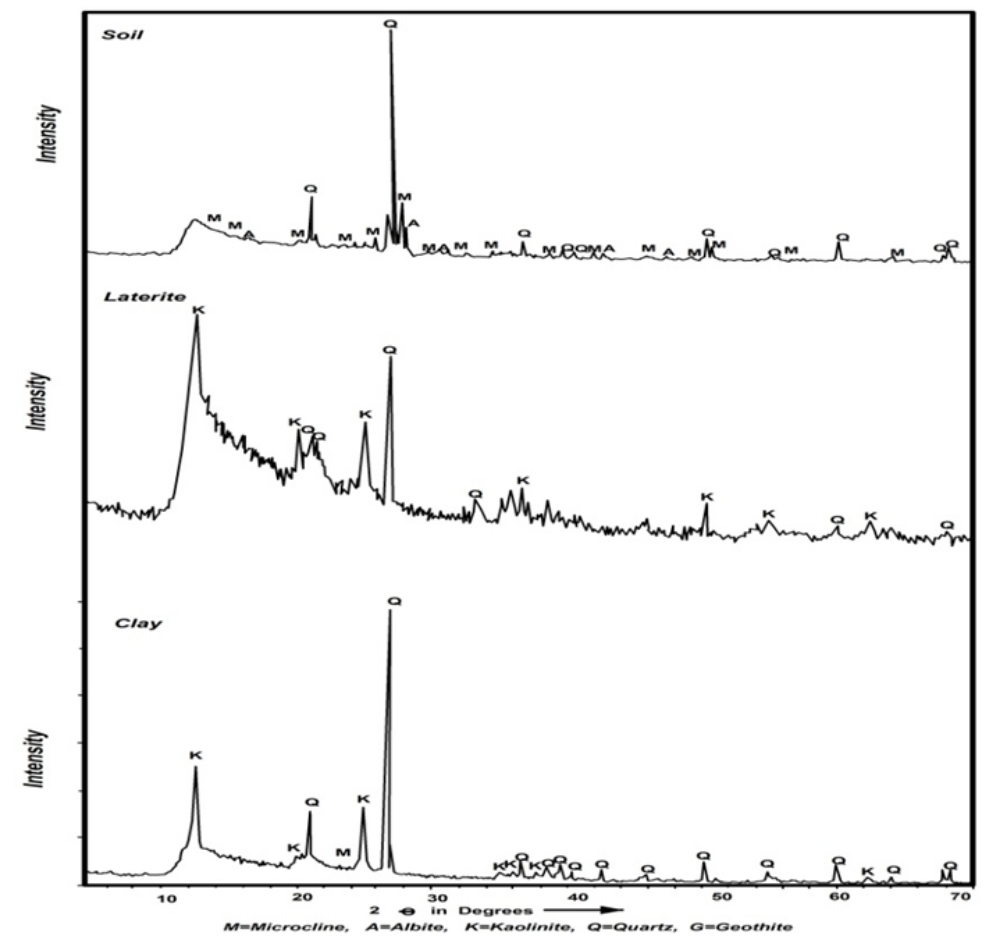

Figure 6. X-ray diffractograms of the weathered profiles above migmatite gneiss at Akure 


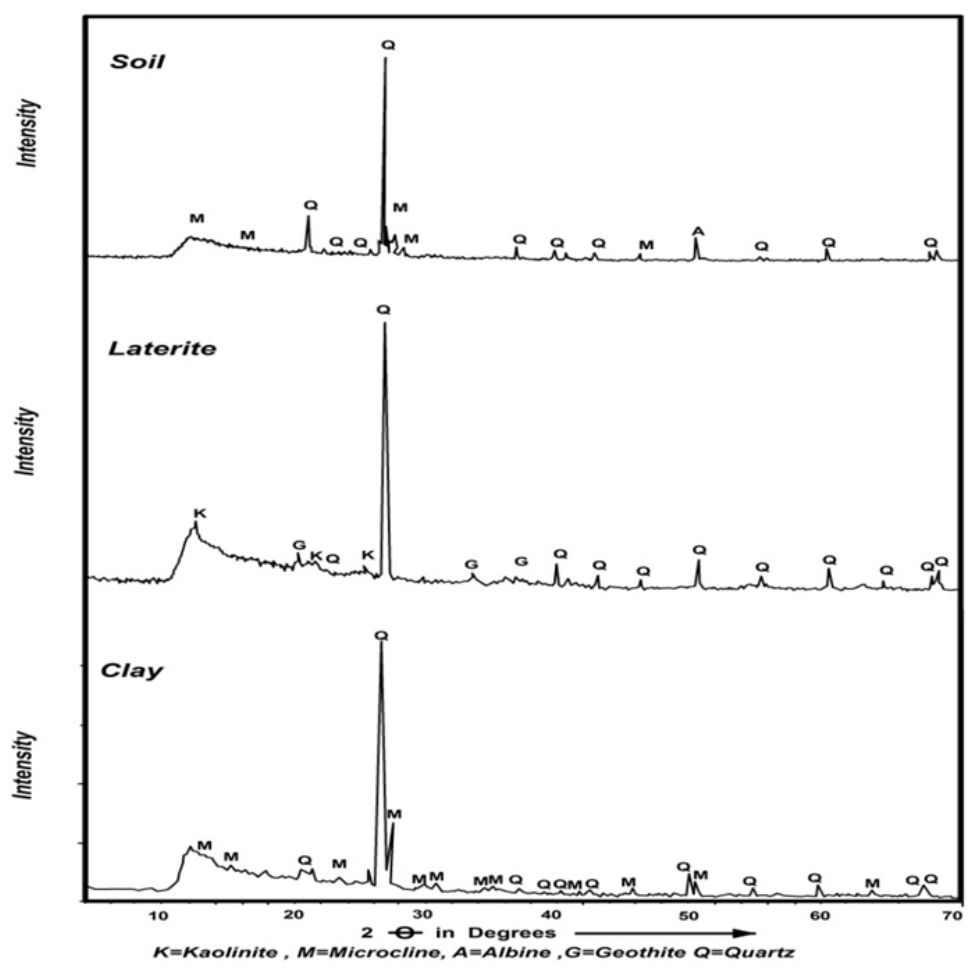

Figure 7. X-ray diffractograms of the weathered profiles above porphyritic granite at Akure

Table 2. Average chemical composition of major (\%) and trace element (ppm) over banded gneiss at Idi-Ayunre area

\begin{tabular}{|c|c|c|c|c|c|c|c|c|}
\hline \multirow[b]{2}{*}{ Oxides } & \multicolumn{2}{|r|}{ Rock } & \multicolumn{2}{|r|}{ Clay } & \multicolumn{2}{|r|}{ Laterite } & \multicolumn{2}{|c|}{ Top soil } \\
\hline & Mean & $\begin{array}{l}\text { Range } \\
\mathrm{n}=5\end{array}$ & Mean & $\begin{array}{l}\text { Range } \\
\mathrm{n}=5\end{array}$ & Mean & $\begin{array}{l}\text { Range } \\
\mathrm{n}=5\end{array}$ & Mean & $\begin{array}{l}\text { Range } \\
\mathrm{n}=5\end{array}$ \\
\hline $\mathrm{SiO}_{2}$ & 68.49 & $67.23-69.75$ & 47.43 & $46.55-47.79$ & 42.64 & $38.77-49.54$ & 44.37 & $43.43-44.96$ \\
\hline $\mathrm{Al}_{2} \mathrm{O}_{3}$ & 15.35 & $14.99-15.17$ & 36.01 & $35.71-36.20$ & 28.59 & $24.67-31.07$ & 22.12 & $19.69-23.34$ \\
\hline $\mathrm{Fe}_{2} \mathrm{O}_{3}$ & 2.85 & $2.56-3.14$ & 2.46 & $1.81-3.76$ & 15.03 & $13.98-16.36$ & 14.25 & $12.73-17.05$ \\
\hline $\mathrm{MgO}$ & 1.18 & $1.02-1.34$ & 0.05 & $0.04-0.08$ & 0.09 & $0.09-0.10$ & 0.23 & $0.22-0.25$ \\
\hline $\mathrm{CaO}$ & 4.34 & $3.98-4.71$ & 0.01 & $0.01-0.01$ & 0.02 & $0.01-0.03$ & 0.37 & $0.34-0.41$ \\
\hline $\mathrm{Na}_{2} \mathrm{O}$ & 4.95 & $4.72-5.18$ & 0.01 & $0.01-0.01$ & 0.01 & $0.01-0.01$ & 0.02 & $0.01-0.04$ \\
\hline $\mathrm{K}_{2} \mathrm{O}$ & 1.31 & $0.19-1.72$ & 0.025 & $0.12-0.49$ & 0.05 & $0.03-0.07$ & 0.21 & $0.18-0.26$ \\
\hline $\mathrm{TiO}_{2}$ & 0.20 & $0.17-0.23$ & 0.84 & $0.68-0.94$ & 1.62 & $1.54-1.75$ & 3.42 & $3.28-3.57$ \\
\hline $\mathrm{P}_{2} \mathrm{O}_{5}$ & 0.14 & $0.12-0.17$ & 0.05 & $0.03-0.09$ & 0.09 & $0.05-0.13$ & 0.20 & $0.17-0.23$ \\
\hline $\mathrm{MnO}$ & 0.05 & $0.05-0.06$ & 0.01 & $0.01-0.01$ & 0.02 & $0.01-0.02$ & 0.14 & $0.12-0.15$ \\
\hline LOI & 0.50 & $0.050-0.51$ & 12.75 & $12.44-12.98$ & 11.68 & $9.90-12.62$ & 14.35 & $13.96-14.87$ \\
\hline Total & 99.36 & & 99.65 & & 99.85 & & 99.68 & \\
\hline \multicolumn{9}{|c|}{ Trace Element (ppm) } \\
\hline $\mathrm{Ba}$ & 610.5 & $622-1130$ & 11 & $5-22$ & 69.3 & $37-136$ & 217.67 & $193-261$ \\
\hline $\mathrm{Sr}$ & 719.5 & $665-780$ & 4 & $2-8$ & 29.3 & $13-45$ & 39.3 & $52-73$ \\
\hline $\mathrm{Zr}$ & 107 & $4-7$ & 504 & $677-827$ & 473 & $433-524$ & 970 & $930-1058$ \\
\hline Y & 19 & $3-7$ & 22.3 & $22-23$ & 13 & $13-15$ & 28.67 & $25-31$ \\
\hline $\mathrm{Nb}$ & & & 41.67 & $18-54$ & 35 & $28-51$ & 1.67 & $43-63$ \\
\hline $\mathrm{Sc}$ & 13 & $1-1$ & 10.67 & $12-18$ & 22 & $22-32$ & 28.3 & $26-30$ \\
\hline \multicolumn{9}{|c|}{ Silica - Aluminum Ratio } \\
\hline SR & 3.77 & $3.97-3.57$ & 1.22 & $1.18-1.24$ & 0.99 & $0.84-1.28$ & 1.23 & $1.18-1.26$ \\
\hline AR & 5.39 & $5.30-6.10$ & 14.63 & $9.50-19.95$ & 1.90 & $1.76-2.10$ & 1.59 & $1.15-1.80$ \\
\hline $\begin{array}{l}\mathrm{MgO}+ \\
\mathrm{CaO}\end{array}$ & 5.52 & $5-6.05$ & 0.6 & $0.56-0.66$ & 0.11 & $0.10-0.13$ & 0.06 & $0.05-0.09$ \\
\hline $\begin{array}{l}\mathrm{Na}_{2} \mathrm{O}+ \\
\mathrm{K}_{2} \mathrm{O}\end{array}$ & 6.26 & $6.09-6.44$ & 0.44 & $0.20-0.81$ & 0.06 & $0.04-0.08$ & 0.26 & $0.13-0.50$ \\
\hline
\end{tabular}


CIA $\quad 57.13 \quad 56.20-58.31 \quad 79.67 \quad 74.57-82.23 \quad 81.39 \quad 81.07-81.64 \quad 71.52 \quad 71.00-71.54$

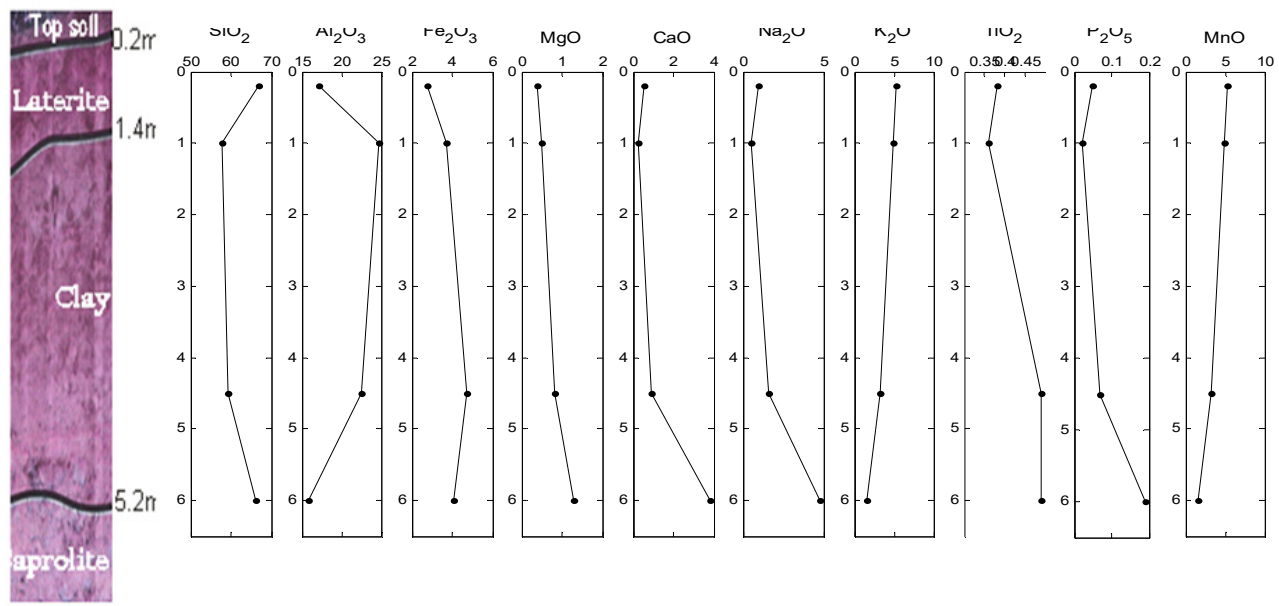

Figure 8. Chemical variation along the weathering profile over biotite gneiss in Idi-Ayunre area

Table 2. Average chemical composition of major (\%) and trace element (ppm) of migmatite gneiss at Akure

\begin{tabular}{|c|c|c|c|c|c|c|c|c|}
\hline & \multicolumn{2}{|r|}{ Rock } & \multicolumn{2}{|r|}{ Clay } & \multicolumn{2}{|r|}{ Laterite } & \multicolumn{2}{|c|}{ Top soil } \\
\hline Oxides & Mean & $\begin{array}{l}\text { Range } \\
\mathrm{n}=5\end{array}$ & Mean & $\begin{array}{l}\text { Range } \\
\mathrm{n}=5\end{array}$ & Mean & $\begin{array}{l}\text { Range } \\
\mathrm{n}=5\end{array}$ & Mean & $\begin{array}{l}\text { Range } \\
\mathrm{n}=5\end{array}$ \\
\hline $\mathrm{SiO}_{2}$ & 68.49 & $67.23-69.75$ & 47.43 & $46.55-47.79$ & 42.64 & $38.77-49.54$ & 44.37 & $43.43-44.96$ \\
\hline $\mathrm{Al}_{2} \mathrm{O}_{3}$ & 15.35 & $14.99-15.17$ & 36.01 & $35.71-36.20$ & 28.59 & $24.67-31.07$ & 22.12 & $19.69-23.34$ \\
\hline $\mathrm{Fe}_{2} \mathrm{O}_{3}$ & 2.85 & $2.56-3.14$ & 2.46 & $1.81-3.76$ & 15.03 & $13.98-16.36$ & 14.25 & $12.73-17.05$ \\
\hline $\mathrm{MgO}$ & 1.18 & $1.02-1.34$ & 0.05 & $0.04-0.08$ & 0.09 & $0.09-0.10$ & 0.23 & $0.22-0.25$ \\
\hline $\mathrm{CaO}$ & 4.34 & $3.98-4.71$ & 0.01 & $0.01-0.01$ & 0.02 & $0.01-0.03$ & 0.37 & $0.34-0.41$ \\
\hline $\mathrm{Na}_{2} \mathrm{O}$ & 4.95 & $4.72-5.18$ & 0.01 & $0.01-0.01$ & 0.01 & $0.01-0.01$ & 0.02 & $0.01-0.04$ \\
\hline $\mathrm{K}_{2} \mathrm{O}$ & 1.31 & $0.19-1.72$ & 0.025 & $0.12-0.49$ & 0.05 & $0.03-0.07$ & 0.21 & $0.18-0.26$ \\
\hline $\mathrm{TiO}_{2}$ & 0.20 & $0.17-0.23$ & 0.84 & $0.68-0.94$ & 1.62 & $1.54-1.75$ & 3.42 & $3.28-3.57$ \\
\hline $\mathrm{P}_{2} \mathrm{O}_{5}$ & 0.14 & $0.12-0.17$ & 0.05 & $0.03-0.09$ & 0.09 & $0.05-0.13$ & 0.20 & $0.17-0.23$ \\
\hline $\mathrm{MnO}$ & 0.05 & $0.05-0.06$ & 0.01 & $0.01-0.01$ & 0.02 & 0.02 & 0.14 & $0.12-0.15$ \\
\hline LOI & 0.50 & $0.050-0.51$ & 12.75 & $12.44-12.98$ & 11.68 & $9.90-12.62$ & 14.35 & $13.96-14.87$ \\
\hline Total & 99.36 & & 99.65 & & 99.85 & & 99.68 & \\
\hline \multicolumn{9}{|c|}{ nt (ppm) } \\
\hline $\mathrm{Ba}$ & 610.5 & $622-1130$ & 11 & $5-22$ & 69.3 & $37-136$ & 217.67 & 193-261 \\
\hline $\mathrm{Sr}$ & 719.5 & $65-780$ & 4 & $2-8$ & 29.3 & & 39.3 & $52-73$ \\
\hline $\mathrm{Zr}$ & 107 & $4-7$ & 504 & $677-827$ & 473 & 433 & 970 & $930-1058$ \\
\hline $\mathrm{Y}$ & 19 & $3-7$ & 22.3 & 3 & 13 & 5 & 28.67 & $25-31$ \\
\hline $\mathrm{Nb}$ & & & 41.67 & & 35 & & 1.67 & $43-63$ \\
\hline $\mathrm{Sc}$ & 13 & 1-1 & 10.67 & & 22 & $2-32$ & 28.3 & $26-30$ \\
\hline \multicolumn{9}{|c|}{ inum Ratio } \\
\hline SR & 3.77 & .57 & 1.22 & & 0.9 & & 1.23 & .26 \\
\hline AR & 5.39 & $5.30-6.10$ & 14.63 & 9.50 & 1.90 & & 1.59 & $1.15-1.80$ \\
\hline $\begin{array}{l}\mathrm{MgO}+ \\
\mathrm{CaO}\end{array}$ & 5.52 & & 0.6 & $5-0.66$ & 0.11 & $0.10-0.13$ & 0.06 & $05-0.09$ \\
\hline $\begin{array}{l}\mathrm{Na}_{2} \mathrm{O}+ \\
\mathrm{K}_{2} \mathrm{O}\end{array}$ & 6.26 & $09-6.44$ & 0.44 & -0.81 & 0.06 & 0.04-0.08 & 0.26 & $0.13-0.50$ \\
\hline
\end{tabular}




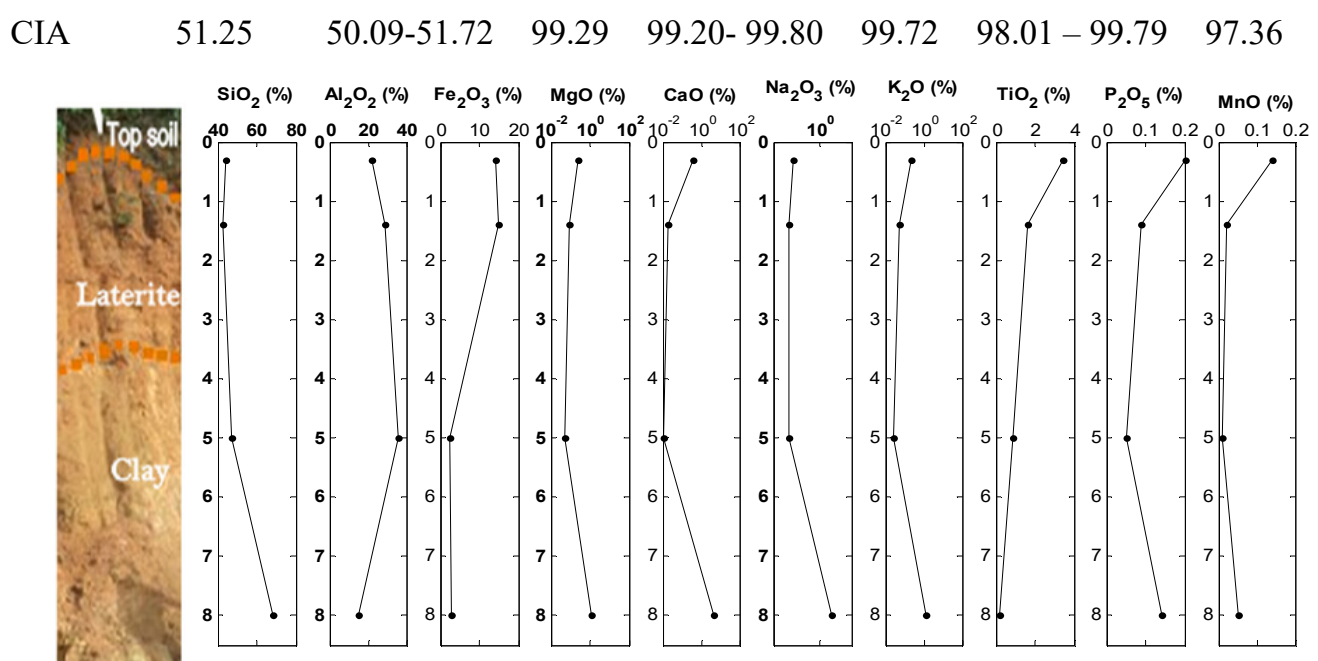

Figure 9. Chemical variation along the weathering profile over migmatite in Akure

Table 3. Average chemical composition of major (\%) and trace element (ppm) over porphyritic granite in Akure.

\begin{tabular}{|c|c|c|c|c|c|c|c|c|}
\hline \multirow{2}{*}{ Oxides } & \multicolumn{2}{|c|}{ Rock } & \multicolumn{2}{|r|}{ Clay } & \multicolumn{2}{|c|}{ Laterite } & \multicolumn{2}{|c|}{ Top soil } \\
\hline & Mean & Range & Mean & Range & Mean & Range & Mean & Range \\
\hline $\mathrm{SiO}_{2}$ & 68.86 & $68.05-69.44$ & 50.11 & $49.43-51.32$ & 46.47 & $45.12-47.38$ & 51.12 & $45.39-62.09$ \\
\hline $\mathrm{Al}_{2} \mathrm{O}_{3}$ & 15.08 & $14.89-15.08$ & 32.34 & $31.71-32.67$ & 28.95 & $27.18-31.91$ & 22.48 & $16.47-25.57$ \\
\hline $\mathrm{Fe}_{2} \mathrm{O}_{3}$ & 3.30 & $2.76-3.79$ & 3.45 & $2.93-4.43$ & 10.02 & $9.31-10.43$ & 8.34 & $5.52-9.92$ \\
\hline $\mathrm{MgO}$ & 1.07 & $0.73-1.53$ & 0.03 & $0.02-0.04$ & 0.09 & $0.08-0.10$ & 0.78 & $0.24-0.28$ \\
\hline $\mathrm{CaO}$ & 3.38 & $3.13-3.67$ & 0.02 & $0.02-0.02$ & 0.03 & $0.01-0.04$ & 0.33 & $0.31-0.36$ \\
\hline $\mathrm{Na}_{2} \mathrm{O}$ & 4.30 & $4.07-4.45$ & 0.01 & $0.01-0.01$ & 0.02 & $0.01-0.05$ & 0.18 & $0.01-0.53$ \\
\hline $\mathrm{K}_{2} \mathrm{O}$ & 1.75 & $1.27-2.05$ & 0.04 & $0.01-0.09$ & 0.58 & $0.18-0.81$ & 2.28 & $0.33-6.18$ \\
\hline $\mathrm{TiO}_{2}$ & 0.42 & $0.31-0.40$ & 2.05 & $0.77-2.70$ & 1.28 & $1.04-1.40$ & 1.54 & $1.50-1.61$ \\
\hline $\mathrm{P}_{2} \mathrm{O}_{5}$ & 0.12 & $0.11-0.14$ & 0.09 & $0.07-0.11$ & 0.34 & $0.06-0.48$ & 0.20 & $0.08-0.27$ \\
\hline $\mathrm{MnO}$ & 0.05 & $0.36-0.38$ & 0.01 & $0.01-0.01$ & 0.02 & $0.01-0.03$ & 0.08 & $0.02-0.13$ \\
\hline LOI & 0.37 & & 11.76 & $11.47-11.93$ & 11.84 & $11.64-12.13$ & 13.00 & \\
\hline Total & 98.39 & & 96.47 & & 99.65 & & 100 & \\
\hline \multicolumn{9}{|c|}{ Trace Element (ppm) } \\
\hline $\mathrm{Ba}$ & 916 & $622-1130$ & 145.3 & $82-178$ & 1102 & $85-1627$ & 963 & $460-1967$ \\
\hline $\mathrm{Sr}$ & 704 & $665-780$ & 57.3 & $24-75$ & 482 & $22-720$ & 207 & $199-213$ \\
\hline $\mathrm{Zr}$ & 5 & $4-7$ & 451 & $267-566$ & 342.67 & $310-390$ & 1119 & $648-2024$ \\
\hline Y & 5 & $3-7$ & 29 & $11-38$ & 68 & 23-91 & 36 & $26-42$ \\
\hline $\mathrm{Nb}$ & & & 50 & $23-65$ & 28 & $22-32$ & 44.3 & $42-49$ \\
\hline $\mathrm{Sc}$ & 5 & $136-163$ & 23 & $19-25$ & 23 & $18-26$ & 17 & $8-22$ \\
\hline \multicolumn{9}{|c|}{ Silica - Aluminum Ratio } \\
\hline SR & 7.84 & $7.42-8.21$ & 1.80 & $1.28-2.82$ & 1.19 & $1.09-1.26$ & 1.80 & $1.28-2.82$ \\
\hline AR & 4.63 & $4.05-5.39$ & 9.37 & $7.16-11.14$ & 2.66 & $2.63-3.43$ & 2.69 & $2.58-2.98$ \\
\hline $\mathrm{MgO}+\mathrm{CaO}$ & 4.45 & $3.86-4.29$ & 2.47 & $0.34-6.71$ & 0.60 & $0.19-0.86$ & 2.47 & $0.34-6.71$ \\
\hline $\mathrm{Na}_{2} \mathrm{O}+\mathrm{K}_{2} \mathrm{O}$ & 6.06 & $5.34-6.45$ & 0.59 & $0.57-0.61$ & 0.12 & $0.11-0.12$ & 0.59 & $0.59-0.6$ \\
\hline
\end{tabular}




\section{CIA 59.1 $59.02-59.40 \quad 99.78$ \\ 99.59-99.88 97.20 \\ 89.14-99.74 $\quad 88.95 \quad 88.52-97.50$}
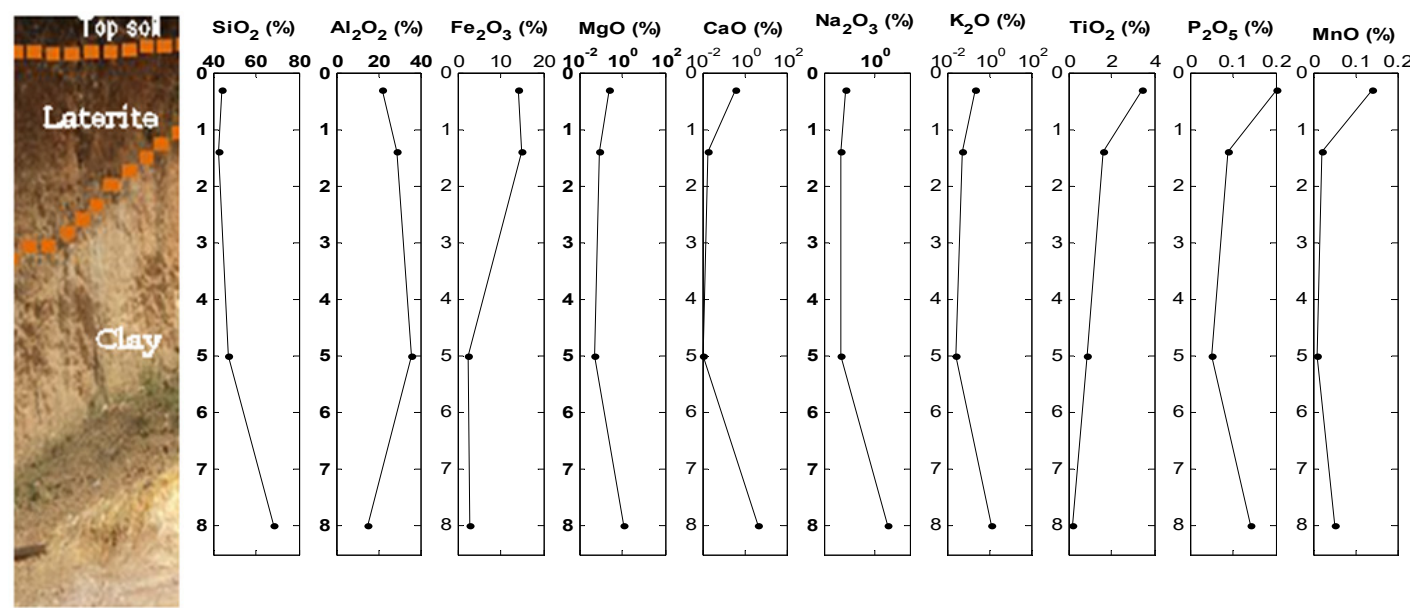

Figure 10. Chemical variation along the weathering profile over migmatite in Akure

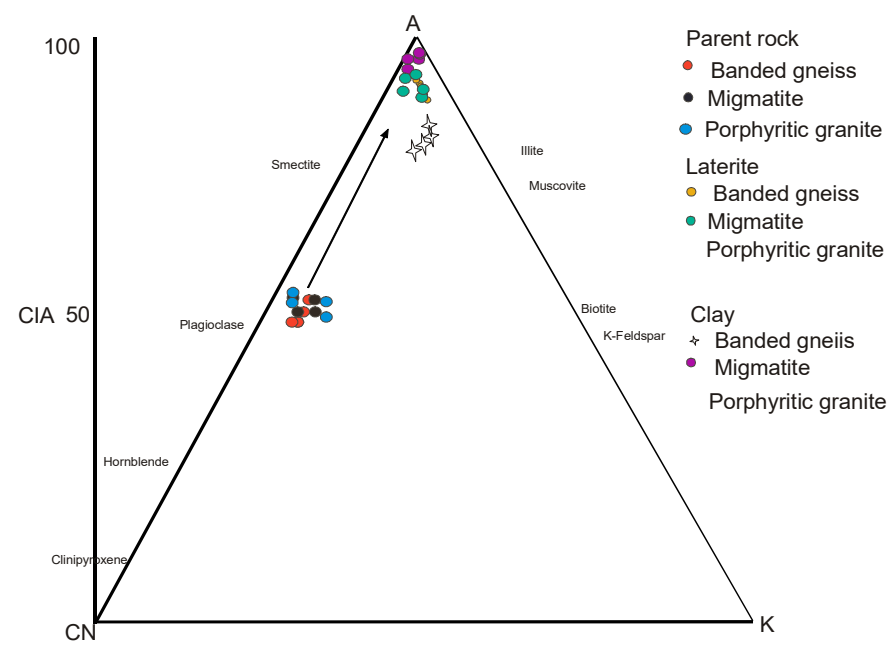

Figure 11. A-CN-K diagram $\left(\mathrm{A}=\mathrm{Al}_{2} \mathrm{O}_{3}, \mathrm{CN}=\mathrm{CaO}+\mathrm{Na}_{2} \mathrm{O}, \mathrm{K}=\mathrm{K}_{2} \mathrm{O}\right)$, all in moles when A-CN-K are recalculated to 100) of weathering profiles from Idi-Ayunre banded gneiss and Akure migmatite and Phorphyritic granite (After Nesbitt and young, 1984) 


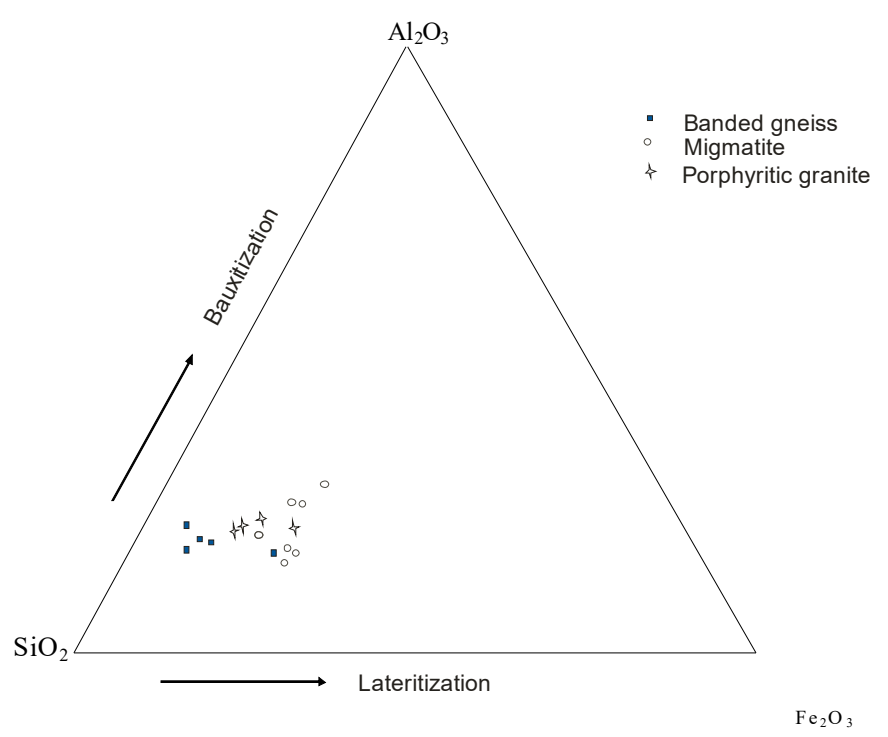

Figure 12. Ternary plot of $\mathrm{SiO}_{2}-\mathrm{Al}_{2} \mathrm{O}_{3}-\mathrm{Fe}_{2} \mathrm{O}_{3}$ o lateritic profiles showing iron enrichment (lateritization) after (Gardner and Walsh 1996)

\section{Copyrights}

Copyright for this article is retained by the author(s), with first publication rights granted to the journal.

This is an open-access article distributed under the terms and conditions of the Creative Commons Attribution license (http://creativecommons.org/licenses/by/3.0/). 